\title{
The inhibitory action of PDCD4 in lipopolysaccharide/ D-galactosamine-induced acute liver injury
}

\author{
Xiaoyan Wang ${ }^{1}$, Lining Zhang ${ }^{1}$, Zengtao Wei $^{2}$, Xia Zhang ${ }^{1,3}$, Qi Gao ${ }^{1}$, Yanyan Ma ${ }^{1}$, Xingli Liu ${ }^{1,4}$, Yang Jiang , \\ Xianglan Liu', Chun Guo ${ }^{1}$ and Xiaoyan Wang ${ }^{1}$
}

Programmed cell death 4 (PDCD4) acts as a tumor suppressor gene, which suppresses tumor growth, infiltration and metastasis. Our previous studies demonstrated that PDCD4 had an important role in the development of ovarian cancer and glioma. Recent studies show that PDCD4 is also involved in various inflammatory diseases. However, its exact effect on inflammation remains unclear. In our current study, we explored the role of PDCD4 in acute liver injury induced by lipopolysaccharide (LPS) and D-galactosamine (D-GaIN) using wild-type (WT) mice and PDCD4-deficient mice. Our results showed that liver-to-body weight ratios, as well as serum aspartate transaminase (AST) and alanine transaminase (ALT) levels were significantly increased in PDCD4-deficient mice than WT mice. Histological examination, immunohistochemical and TUNEL analysis revealed PDCD4-deficient mice had more necrotic and apoptotic hepatocytes, inflammatory cells infiltration and liver internal hemorrhage than WT mice. In addition, some inflammatory cytokines such as tumor necrosis factor- $\alpha$ (TNF- $\alpha$ ), interleukin-6 (IL-6) in the serum and liver tissues were also significantly increased in PDCD4-deficient mice. More importantly, we found that the aggravation of liver tissue injury in PDCD4-deficient mice was due to excessive mitogen-activated protein kinase and NF- $\kappa$ B activation, which induced the release of more inflammatory factors, and consequently resulted in higher levels of hepatocyte necrosis and apoptosis. These results indicate that PDCD4 has a protective role in LPS/D-GalN-induced acute liver injury. This finding may present new opportunities for PDCD4 to be explored as a therapeutic target in acute liver injury.

Laboratory Investigation (2013) 93, 291-302; doi:10.1038/labinvest.2012.174; published online 7 January 2013

KEYWORDS: acute liver injury; D-GalN; inflammatory cytokines; LPS; PDCD4

Programmed cell death 4 (PDCD4) has been identified as a tumor suppressor gene, ${ }^{1,2}$ which suppresses tumor growth, infiltration and metastasis by regulating the expression of various genes related to tumor promotion and progression at transcriptional and translational levels. Our previous studies also demonstrated that PDCD4 had an important role in the development of ovarian cancer $^{3-5}$ and glioma. ${ }^{6,7}$ Recent studies show that PDCD4 is also involved in various inflammatory diseases. It has been reported that PDCD4deficient mice are resistant to streptozotocin-induced type II diabetes and experimental autoimmune encephalomyelitis, ${ }^{8}$ and are also protected from the lethality of lipopolysaccharide (LPS). ${ }^{9}$ These results indicate that PDCD4 is a pro-inflammation protein. However, some other reports have shown that knockdown of PDCD4 increases TNF- $\alpha$ protein production in LPS-stimulated RAW264.7 macrophages and indicate that PDCD4 is an anti-inflammatory factor. ${ }^{10}$ Therefore, the exact role of PDCD4 in inflammatory diseases remains to be investigated.

Intestinal endotoxemia-induced acute liver injury is a common inflammatory disease leading to acute liver failure and death in the clinic. ${ }^{11}$ It is induced by cell wall components of Gram-negative bacteria-LPS, which is a potent activator of kupffer cells and endothelial cells. LPS stimulates kupffer cells to produce and release inflammatory factors such as tumor necrosis factor- $\alpha$ (TNF- $\alpha$ ), Interleukin (IL)-1 $\beta$, IL-6, etc. ${ }^{12,13}$ The inflammatory response mainly depends on the activation of mitogen-activated protein

\footnotetext{
'Department of Immunology, Shandong University School of Medicine, Jinan, China; ${ }^{2}$ Shandong University School of Medicine, Jinan, China; ${ }^{3}$ Department of Clinical Laboratory, Yuhuangding Hospital, Yantai, China and ${ }^{4}$ Department of Children's Medical Laboratory Diagnosis Center, Qilu Children's Hospital of Shandong University, Jinan, China

Correspondence: Dr X Wang, Associate Professor of Immunology, Department of Immunology, Shandong University School of Medicine, 44\# Wenhua Xi Road, Jinan, Shandong 250012, China.

E-mail:wxy990809@163.com

Received 12 July 2012; revised 25 October 2012; accepted 24 November 2012
} 
kinases (MAPK) and NF- $\kappa$ B pathways. ${ }^{14}$ These inflammatory factors, especially TNF- $\alpha$, can further induce hepatocyte apoptosis and necrosis. During this process, kupffer cells have a crucial role in determining the inflammatory response to LPS and hepatocytes are the major target cells. D-galactosamine (D-GalN) is a kind of amino sugar, which induces the depletion of uridine triphosphate pool and increases the hepatotoxicity of LPS. LPS in combination with $\mathrm{D}-\mathrm{GalN}$ can induce specific liver injury, but has no effect on other organs, such as the heart, spleen and lung. ${ }^{15,16}$ Therefore, LPS/D-GalN-induced hepatitis is a wellestablished model to mimic liver injury induced by intestinal endotoxemia in a clinical setting. ${ }^{17-19}$

The present study aims to examine the in vivo role of PDCD4 in LPS/D-GalN-induced liver injury using PDCD4-deficient mice and wild-type (WT) mice. We first demonstrated that PDCD4 deficiency exacerbated LPS/DGalN-induced hepatocyte apoptosis and necrosis, and enhanced liver injury in PDCD4-deficient mice was due to an increased release of inflammatory factors induced by excessive activation of the MAPK and NF- $\kappa \mathrm{B}$ pathways.

\section{MATERIALS AND METHODS Reagents}

Rabbit polyclonal antibodies specific for caspase-3, cleaved caspase-3 (Asp175); ERK1/2, Phospho (p)-ERK1/2 (Thr202/ Tyr204); SAPK/JNK (Jun N-terminal kinase), p-SAPK/JNK (Thr183/ Tyr185); p38 MAPK, p-p38 MAPK (Thr180/ Tyr182) were purchased from Cell Signaling Technology. Polyclonal rabbit anti-phospho-NF- $\kappa \mathrm{B}$ p65 (anti-p-p65) (Ser529) was purchased from Abcam. Anti-rabbit IgG conjugated with horseradish peroxidase (HRP) was purchased from Cell Signaling Technology. LPS and D-GalN were purchased from Sigma-Aldrich.

\section{Animal Experiments}

PDCD4-deficient $\left(P d c d 4^{-/-}\right)$and WT C57BL/6 mice were kindly provided by Dr Youhai Chen, University of Pennsylvania. All animals were fed with sterile water and food under specific pathogen-free conditions. All animal studies were approved by the Animal Care and Use Committee of the Institute of Zoology, Chinese Academy of sciences. PDCD4deficient mice at the age of 6-8 week and body weight of $16-18 \mathrm{~g}$ were used in all the experiments, with age- and sexmatched WT C57BL/6 mice as controls. The animal number per group for every time point is 8 . For induction of acute liver injury, mice were administered intraperitoneally LPS $(50 \mathrm{~g} / \mathrm{kg})$ and D-GalN $(800 \mathrm{mg} / \mathrm{kg})$. Mice were killed at 0,3 , $5 \mathrm{~h}$ after LPS/D-GalN administration. Blood was obtained from the retro-orbital venous plexus. Serum was collected after centrifugation at 3000 r.p.m. for $10 \mathrm{~min}$ at $4{ }^{\circ} \mathrm{C}$. Liver tissues were removed and preserved for subsequent RNA and protein analysis as well as histological studies.

\section{Hematoxylin and Eosin Staining of Liver Sections}

For pathological analysis, liver tissues were fixed overnight in $10 \%$ formalin solution then dehydrated and embedded in paraffin. Liver sections $(4 \mu \mathrm{m})$ were stained with hematoxylin and eosin.

\section{Immunohistochemical Analysis of Liver Tissues}

The liver tissue sections $(4 \mu \mathrm{m})$ were subjected to immunohistochemical analysis for cleaved caspase-3 and p-p65 using Histostain-Plus Kit (Beijing 4A Biotech). The sections were deparaffinized in xylene and rehydrated in graded ethanol, followed by antigen microwave retrieval. The slides were blocked with $3 \% \mathrm{H}_{2} \mathrm{O}_{2}$ and Reagent A (10\% goat serum) and then incubated overnight at $4{ }^{\circ} \mathrm{C}$ with anticleaved caspase-3 (1:100) or anti-p-p65 (1:50). The slides were successively incubated at $37^{\circ} \mathrm{C}$ for $15 \mathrm{~min}$ with Reagent B (biotinylated goat anti-rabbit) and Reagent C (Streptavidin/ HRP). Diaminobenzidine was used to show color and followed by counterstaining with hematoxylin.

\section{TUNEL Assay of Liver Sections}

Liver sections $(4 \mu \mathrm{m})$ were deparaffinized and rehydrated. TUNEL assay was performed using the In Situ Cell Death Detection Kit, Fluorescein (Roche). For each liver section per mouse, the number of TUNEL-positive cells in three randomly selected high power fields $(\times 200)$ was counted under the fluorescence microscopy, and the percentages of TUNELpositive cells (Apoptotic cells \%) were calculated.

\section{Analysis of Alanine Transaminase (ALT) and Aspartate Transaminase (AST) in Serum}

Blood samples were collected at $0,3,5 \mathrm{~h}$ after LPS/D-GalN administration. After centrifugation, serum samples were stored at $-80^{\circ} \mathrm{C}$. Serum ALT and AST levels were measured by an automatic biochemical analyzer (Siemens, DimensionRLMax) as indicators for hepatocyte degeneration and necrosis.

\section{Analysis of Cytokines in Serum}

Serum samples were collected as described above. Serum levels of TNF- $\alpha$, IL-6, IL-10, MCP-1 (monocyte chemoattractant protein-1) and IL-12p70 were measured with BD Cytometric Bead Array MOUSE Inflammation Kit (Becton, Dickinson and Company) in accordance with the manufacturer's instruction. Serum IL-1 $\beta$ level was determined with an ELISA kit (eBioscience) specific for murine IL-1 $\beta$ according to the manufacturer's instruction.

\section{Analysis of Cytokines mRNA Expression in Liver Tissue by RT-PCR}

Liver tissues were removed from the mice and frozen immediately in liquid nitrogen. Total RNA was extracted using a modified TRIzol one-step extraction method (Invitrogen). cDNA was synthesized using an Rever Tra Ace qPCR kit (TOYOBO) according to the manufacturer's instruction and 
Table 1 Primer sequences used for RT-PCR analysis of liver tissue

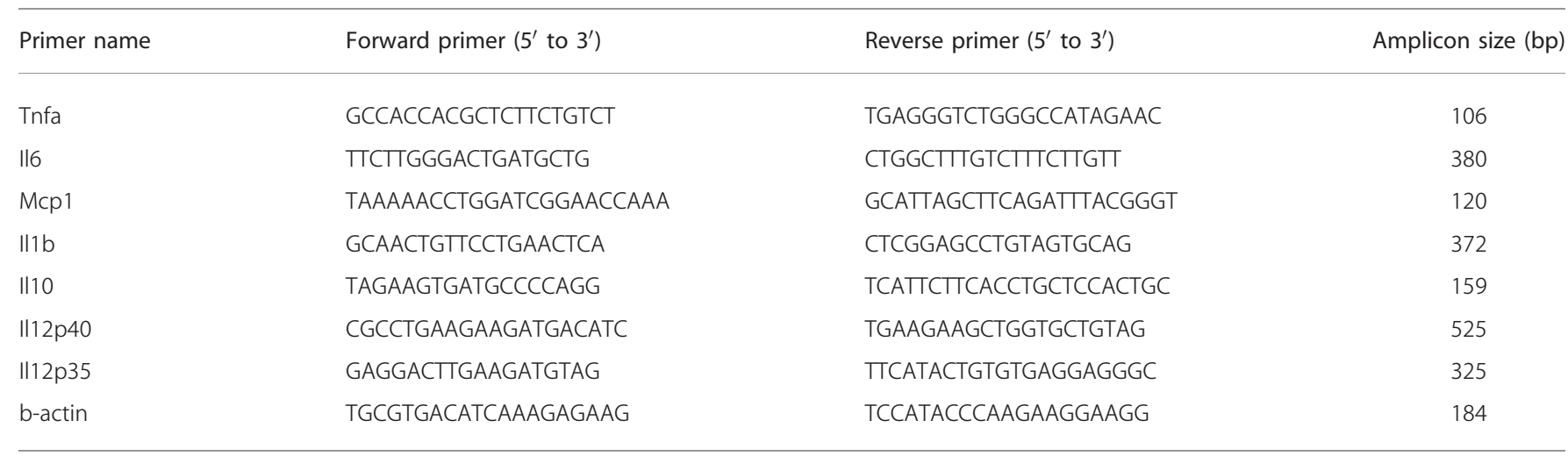

amplified with PCRmix (Transgen) and specific primers (Table 1). The PCR products were run on a $2 \%$ agarose gel and subjected to densitometric scanning using the Multilmager (BIO-RAD), and the bands were quantified with analysis software (Quantity One).

\section{Western Blot Analysis of Liver Tissues}

Liver total proteins were isolated and $40 \mu \mathrm{g}$ of proteins were separated on SDS-polyacrylamide gel. After electrophoresis, proteins were electrotransferred to PVDF membranes (Millipore, Billerica, MA, USA). The membranes were incubated overnight at $4{ }^{\circ} \mathrm{C}$ with $1: 1000$ dilution of anti-caspase-3, ERK1/2, p-ERK1/2; SAPK/JNK, p-SAPK/JNK; p38 MAPK, p-p38 MAPK, and 1:300 dilution of anti-p-p65, respectively, followed by a 1:2000 dilution of secondary antibodies conjugated with HRP for $1 \mathrm{~h}$ at room temperature. Finally, the membranes were visualized by the ECL western blotting detection system according to the manufacturer's instruction. $\beta$-actin was used as the loading control. Densitometry analysis was performed to quantify protein bands.

\section{Statistical Analysis}

All data were expressed as mean \pm s.d. and analyzed using Student's $t$ test. Differences were considered to be significant if $P$ values were $<0.05$.

\section{Results}

PDCD4 Deficiency Promotes Hepatocytes Apoptosis and Necrosis in LPS/D-GaIN-induced Acute Liver Injury

To study the roles of PDCD4 in LPS/D-GalN-induced acute liver injury, we injected intraperitoneally LPS and D-GalN in PDCD4-deficient $\left(P d c d 4^{-/-}\right)$mice and WT mice. At $3 \mathrm{~h}$ after LPS/D-GalN injection, liver-to-body weight ratios were a little high and serum ALT, AST levels were slightly low in PDCD4-deficient mice compared with WT mice, but there were no statistical significant differences. The results of histological examination also showed no significant differences between the two groups. However, $5 \mathrm{~h}$ later, liver-to-body weight ratios, serum ALT and AST levels in PDCD4-deficient mice were significantly higher than those in WT mice (Figures 1a, b and c). Histological observation showed that the liver tissues of PDCD4-deficient mice displayed the loss of structural integrity. PDCD4-deficient mice had more obvious degenerative, necrotic hepatocytes and liver internal hemorrhage than WT mice. In addition, the infiltration of some lymphocytes and few neutrophils was also found in the sections of PDCD4-deficient mice (Figure 1d).

Hepatocyte apoptosis is another important pathological morphology besides the necrosis of hepatocytes during LPS/ D-GalN-induced acute liver injury. We further addressed the question whether PDCD4 deficiency could affect the hepatocyte apoptosis. There were no significant differences in hepatocyte apoptosis between PDCD4-deficient mice and WT mice at $3 \mathrm{~h}$ after LPS/D-GalN injection, but at $5 \mathrm{~h}$ after injection, the result of TUNEL assay showed the number of TUNEL-positive cells in liver tissues of PDCD4-deficient mice was significantly increased compared with WT mice (Figures $2 \mathrm{a}$ and $\mathrm{b}$ ). In addition, the results from the immunohistochemical and western blot analysis showed that the expression of cleaved caspase-3 was significantly higher in the liver tissues of PDCD4-deficient mice than that in WT mice (Figures $2 \mathrm{c}$ and $\mathrm{d}$ ). These results indicate that PDCD4 deficiency potentiates LPS/D-GalN-induced hepatocyte apoptosis and necrosis, and PDCD4 provides a hepatoprotective effect.

\section{PDCD4 Deficiency Altered Serum Cytokine Levels in LPS/D-GaIN-induced Acute Liver Injury}

During LPS/D-GalN-induced acute liver injury, hepatocyte apoptosis and necrosis are mainly caused by the release of LPS-induced proinflammatory cytokines, such as TNF- $\alpha$, IL$1 \beta$, IL-6, etc. Among them, TNF- $\alpha$ is a key mediator in LPS/ $\mathrm{D}$-GalN-induced acute liver injury. To further examine whether PDCD4 deficiency can alter the expression of inflammatory cytokines, and then increase the susceptibility of LPS/D-GalN administration, we first detected the levels of 
TNF- $\alpha$, IL-1 $\beta$, IL-6, MCP-1, IL-10, IL-12p70 in serum. The results showed that serum TNF- $\alpha$ levels in PDCD4-deficient mice were significantly higher than those in WT mice at $3 \mathrm{~h}$ after injection of LPS/D-GalN (Figure 3a). Compared with $3 \mathrm{~h}$ after injection, serum TNF- $\alpha$ levels decreased approximately $30 \%$ at $5 \mathrm{~h}$ after injection in PDCD4-deficient mice.
While serum TNF- $\alpha$ levels in WT mice had no significant changes at $3 \mathrm{~h}$ and $5 \mathrm{~h}$ after injection (Figure $3 \mathrm{a}$ ). Therefore, there were no significant differences in the levels of serum TNF- $\alpha$ between PDCD4-deficient mice and WT mice at $5 \mathrm{~h}$ after LPS/D-GalN injection (Figure 3a). The variation tendency of serum IL-6 levels was similar to that of serum TNF- $\alpha$ a

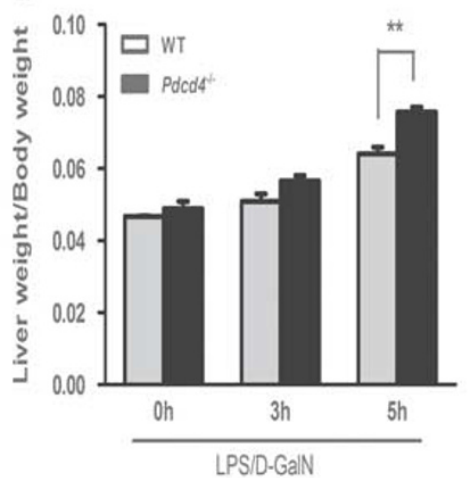

d
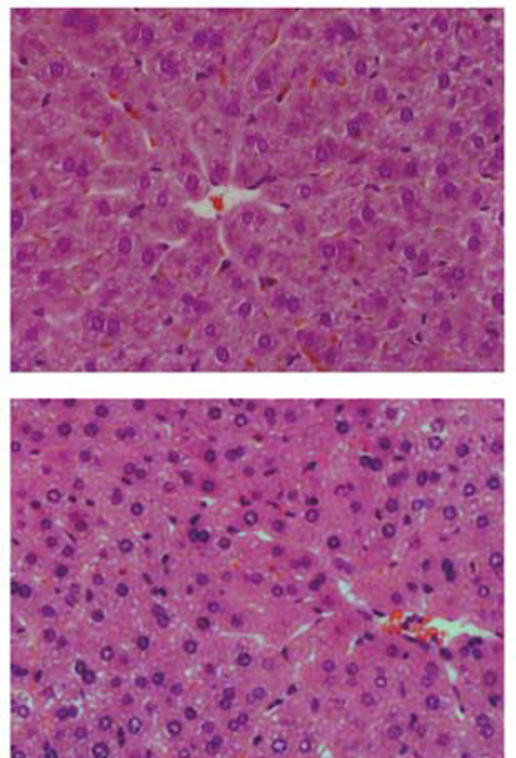

Oh b
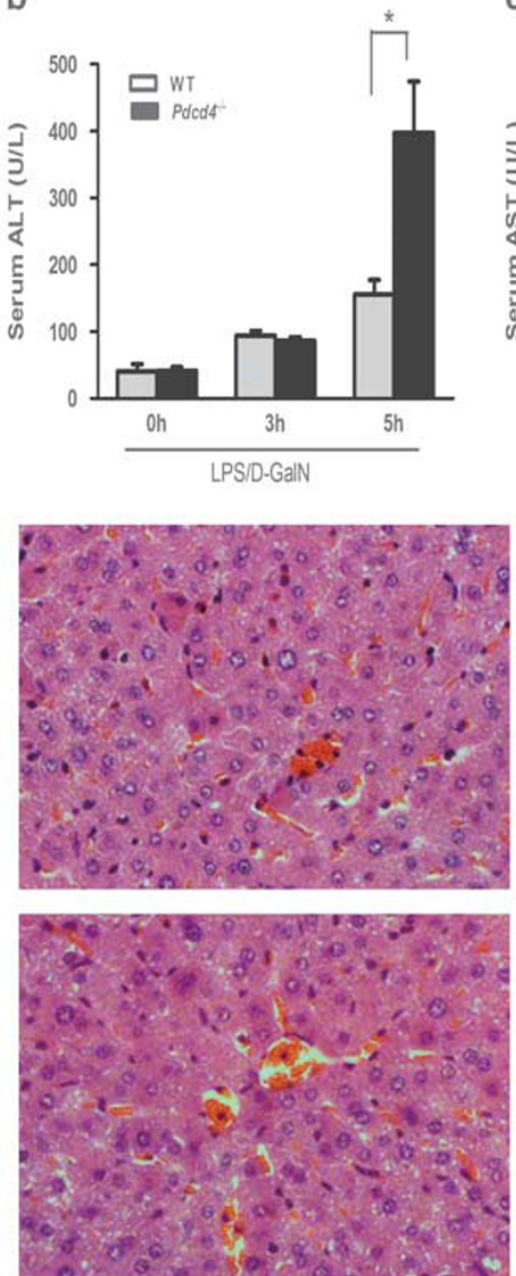

$3 \mathrm{~h}$
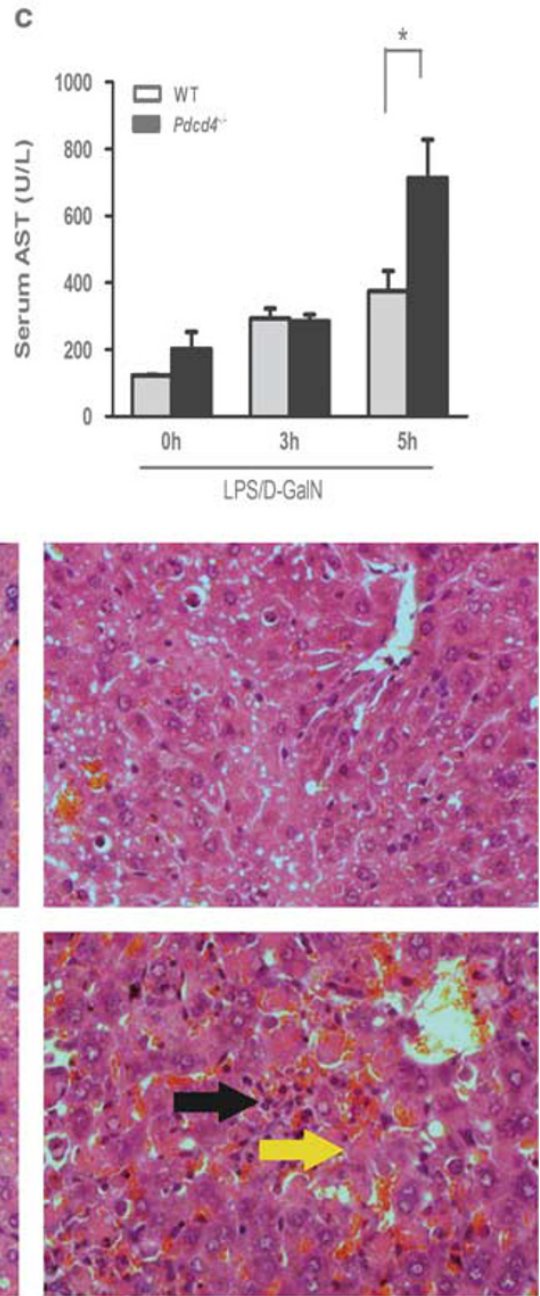

$5 \mathrm{~h}$

Figure 1 PDCD4 deficiency increased the sensitivity to LPS/D-GalN-induced acute liver injury. PDCD4-deficient mice and WT mice were i.p. injected with LPS $(100 \mu \mathrm{g} / \mathrm{kg})$ and GalN $(800 \mathrm{mg} / \mathrm{kg})$. ( $n=8 / \mathrm{group} /$ time point) (a) Liver-to-body weight ratios in PDCD4-deficient $\left(\right.$ Pdcd4 $\left.^{-/-}\right)$mice were significantly higher than those in WT mice at $5 \mathrm{~h}$ post LPS/D-GalN injection $\left({ }^{*} P<0.01\right)$. (b, c) $P d c d 4^{-1-}$ mice had higher serum ALT and AST levels than WT mice at $5 \mathrm{~h}$ after LPS/D-GalN administration $\left({ }^{*} P<0.05\right)$. (d) Representative H\&E liver sections showed that the liver tissues of $P d c d 4^{-/-}$mice displayed loss of structural integrity, $P d c d 4^{-1-}$ mice had more obvious degenerative, necrotic hepatocytes and liver internal hemorrhage than WT mice at $5 \mathrm{~h}$ after injection. In addition, the infiltration of some lymphocytes and few neutrophils was also found in the sections of PDCD4-deficient mice. The black arrow points to the lymphocyte cells and the yellow arrow points to the necrotic hepatocytes found in the sections. Original magnification: $\times 200$.

Figure 2 PDCD4 deficiency promote hepatocytes apoptosis in LPS/GalN-induced liver injury. ( $n=8 /$ group/time point) (a) TUNEL assay (FITC labeling, green highlight spots, $\times 200$ ) showed the number of TUNEL-positive cells in liver sections of $P d c d 4^{-1-}$ mice was significantly increased compared with WT mice at $5 \mathrm{~h}$ post LPS/D-GalN injection. (b) The histogram represented the percentages of apoptotic cells in the liver sections of $P d c d 4^{-1-}$ and WT mice. ${ }^{* *} P<0.01$ compared with WT mice. (c, d) Immunohistochemical and western blot analysis showed that the expression of cleaved caspase-3 was significantly higher in the liver tissues of $P d c d 4^{-1-}$ mice than that in WT mice at $5 \mathrm{~h}$ after injection. Original magnification: $\times 200$. (e) The histogram represented semiquantitative results (mean \pm s.d.) of western blot analysis of caspase- $3(* P<0.05)$. 
a
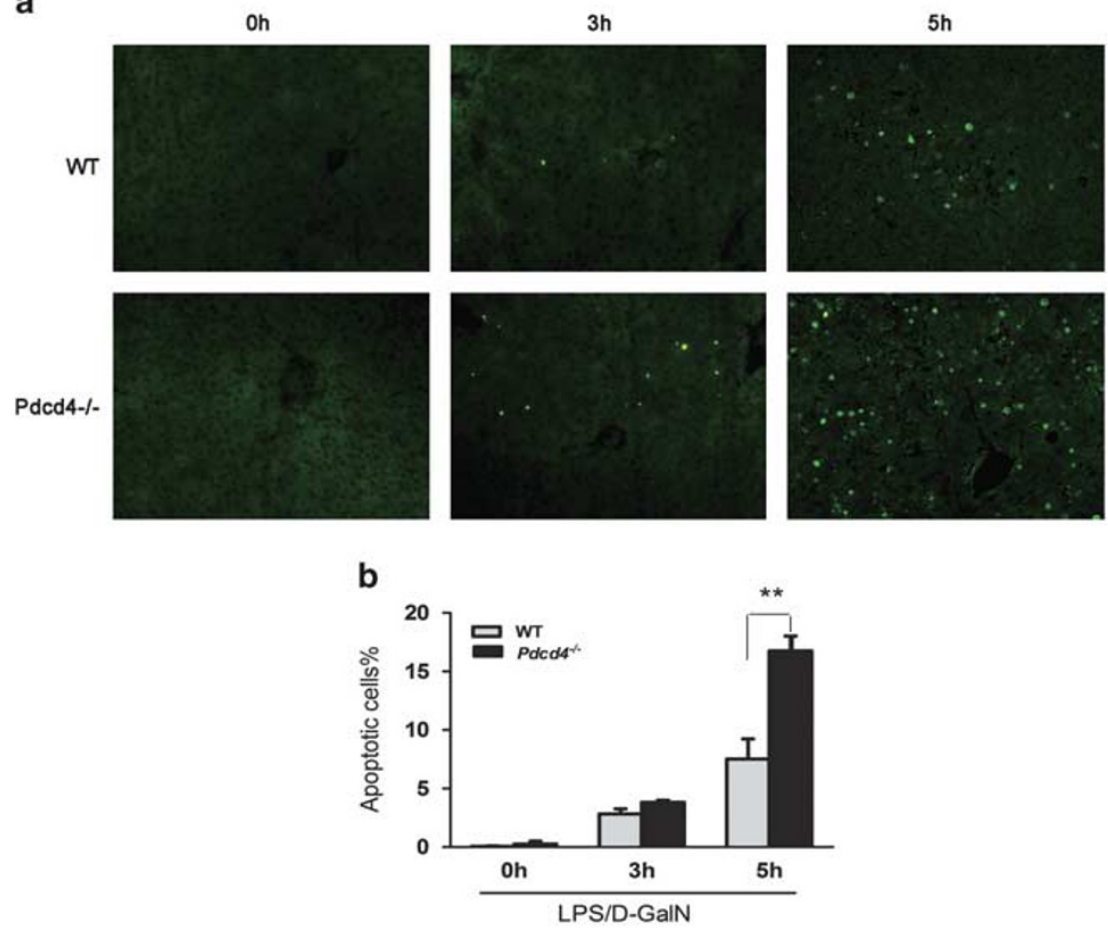

C

Oh
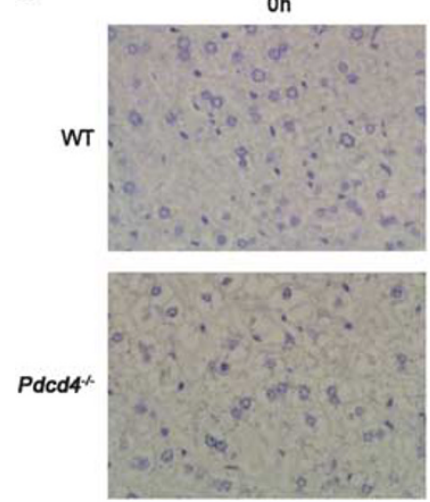

d

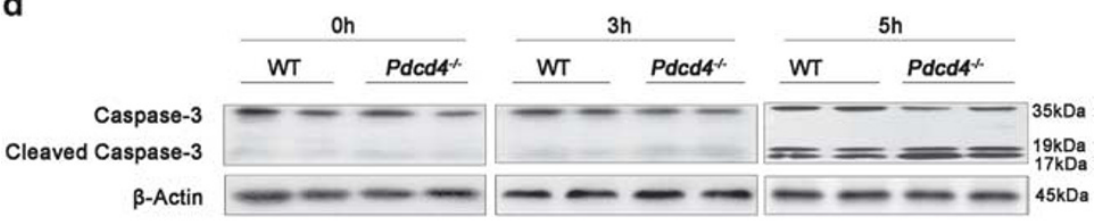

$3 \mathrm{~h}$
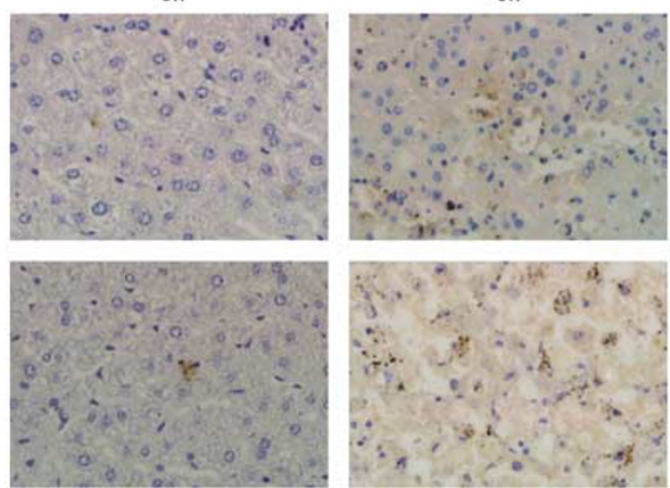

$5 \mathrm{~h}$

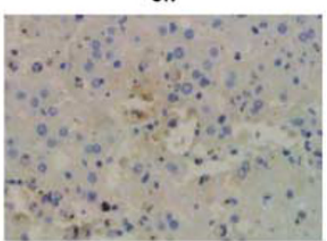

e

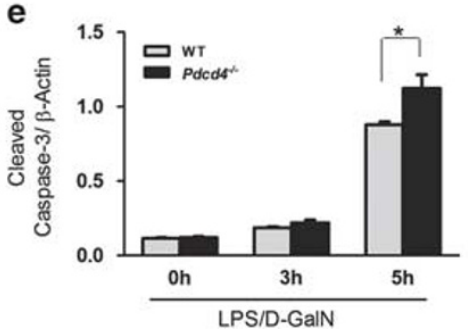



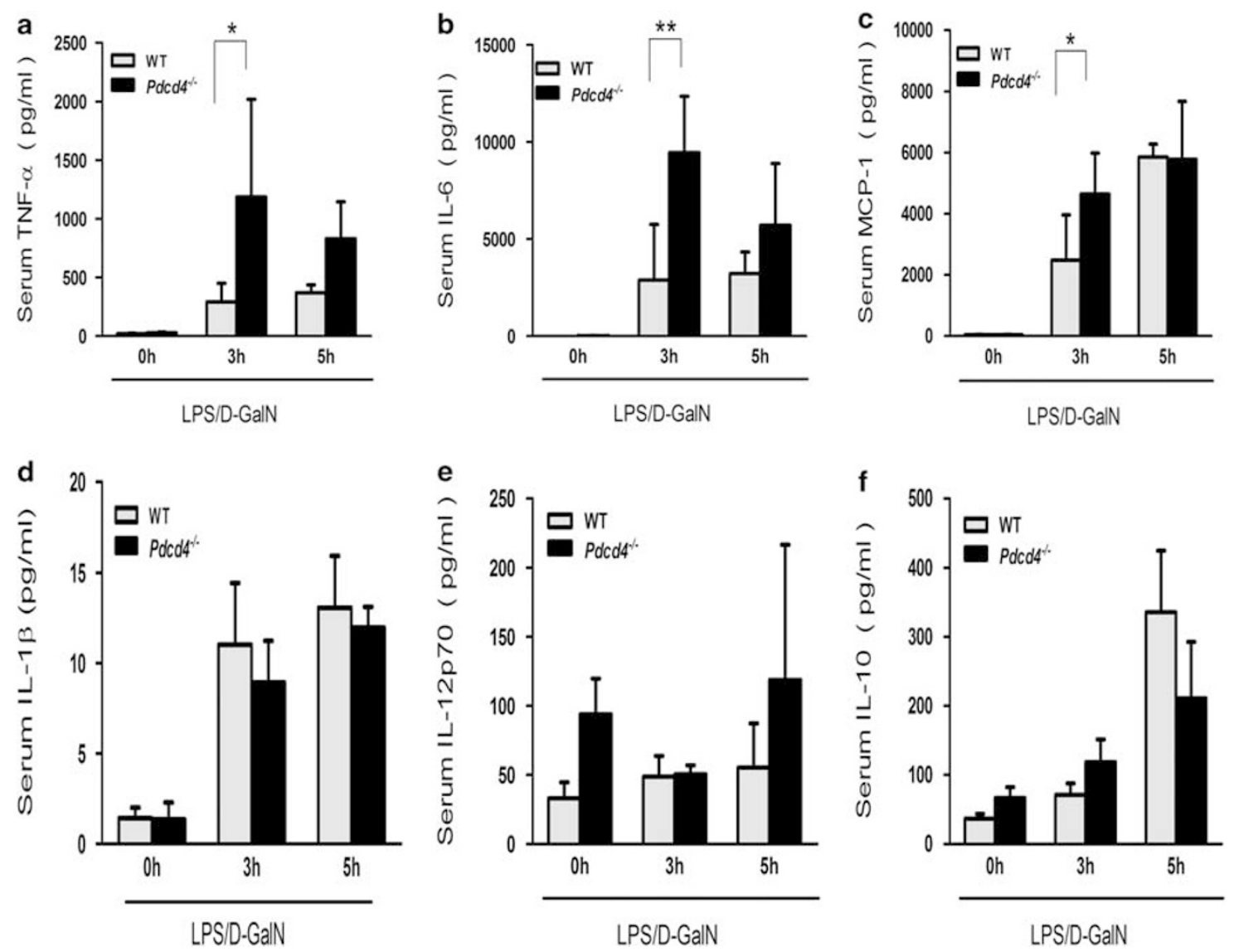

Figure 3 PDCD4 deficiency altered serum cytokine levels in LPS/D-GalN-induced acute liver injury. ( $n=8 /$ group/time point) (a-c) Serum TNF- $\alpha$, IL-6 and MCP-1 levels of $P d c d 4^{-1-}$ mice were significantly higher than those of WT mice at $3 \mathrm{~h}$ after injection of LPS/D-GaIN $\left({ }^{*} P<0.05,{ }^{* *} P<0.01\right)$. (d-f) Serum levels of IL-1 $\beta$, IL-12p70 and IL-10 were no significant differences between Pdcd4 $4^{-/-}$mice and WT mice at the same time point after injection of LPS/ D-GalN $(P>0.05)$.

levels (Figure 3b). In addition, we found that serum MCP-1 levels in PDCD4-deficient mice were also significantly increased than those in WT mice at $3 \mathrm{~h}$ after injection (Figure 3c). However, the levels of serum proinflammatory cytokines IL-1 $\beta$, IL-12p70 and anti-inflammatory factor IL-10 were no significant differences between PDCD4-deficient mice and WT mice at the same time point after injection of LPS/D-GalN (Figures 3d-f).

\section{PDCD4 Deficiency Altered Hepatic Cytokine Levels in LPS/D-GaIN-induced Acute Liver Injury}

In order to explore the effect of PDCD4 deficiency on the expression of inflammatory cytokines, we further detected mRNA expression of cytokine genes (Tnfa, Illb, Il6, Mcpl, Il10, Il12p40, Il12p35) in liver tissues by RT-PCR. As shown in Figures $4 \mathrm{a}-\mathrm{d}, 3 \mathrm{~h}$ after LPS/D-GalN administration, there was significantly increased expression of proinflammatory cytokines Tnfa, Illb, Il6 and Mcp1 mRNA in PDCD4-deficient mice. However, anti-inflammatory factor Ill0 mRNA expression in PDCD4-deficient mice was also significantly higher than that in WT mice at $3 \mathrm{~h}$ after LPS/D-GalN ad- ministration (Figure 4e). There were no significant differences in the expression of Il12p40 and Il12p35 mRNA between the two groups at the same time point (Figures $4 \mathrm{f}$ and g).

\section{PDCD4 Deficiency Promotes LPS-induced Activation of MAPK in the Liver}

The inflammatory response induced by LPS mainly depends on the activation of MAPK. To understand whether PDCD4 deficiency promotes LPS-induced production and release of inflammatory cytokines by activating the MAPK pathway, we detected the expression of MAPK and corresponding phosphorylated MAPK, including ERK1/2, p-ERK1/2; SAPK/JNK, p-SAPK/JNK; p38 MAPK, p-p38 MAPK in liver tissues of PDCD4-deficient mice and WT mice. The results showed that the expression of hepatic p-ERK1/2 in PDCD4-deficient mice was a little lower than that in WT mice at $0 \mathrm{~h}$ after LPS/DGalN injection. Three hours later, p-ERK1/2 levels were both increased, but there was no significant difference between the two groups. At $5 \mathrm{~h}$ after administration, $\mathrm{p}$-ERK1/2 levels were significantly higher in PDCD4-deficient mice than WT mice 
a

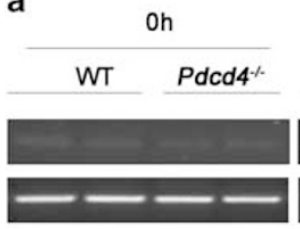

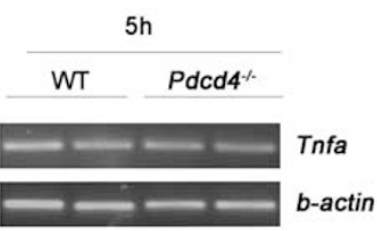

b-actin

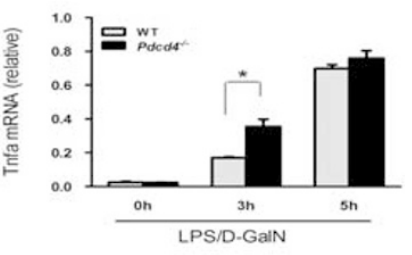

b
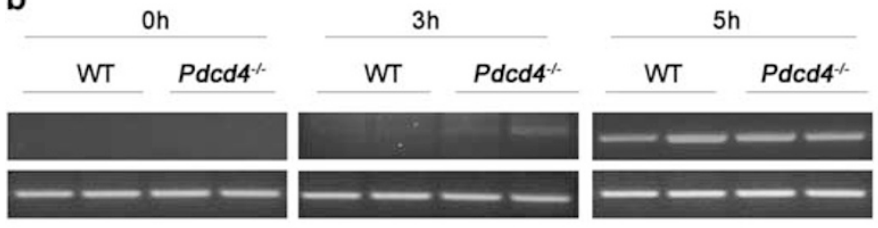

116

b-actin

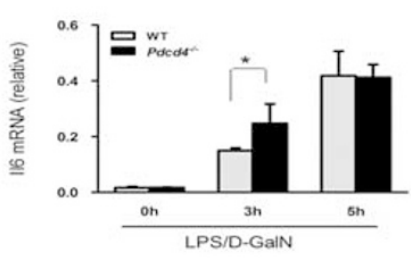

C
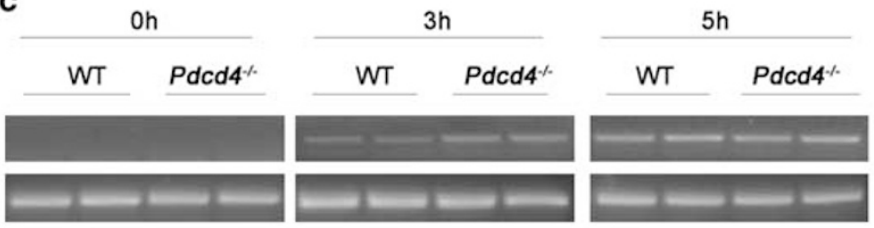

Mcp1

b-actin

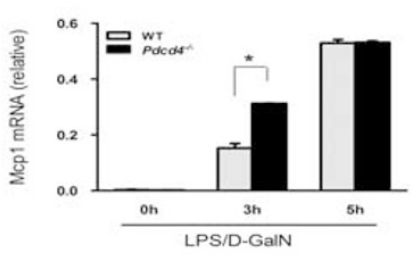

d
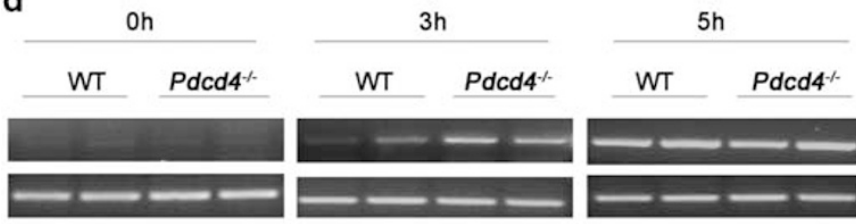

II1b

b-actin

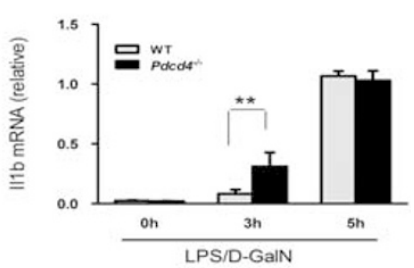

e
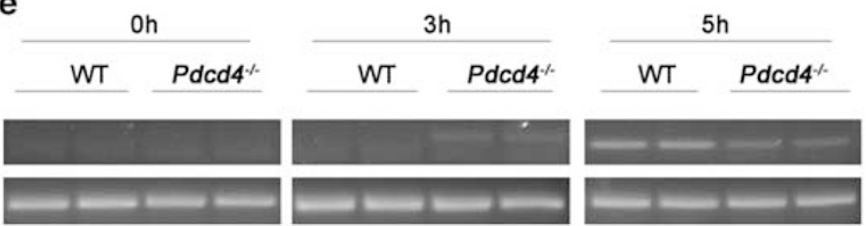

1110

b-actin

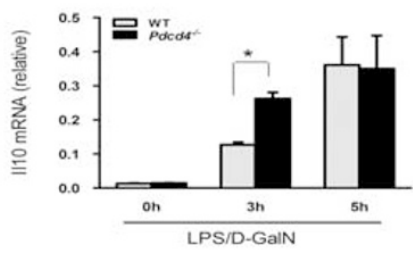

f
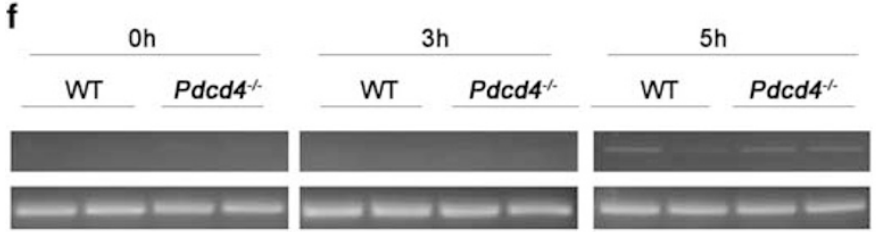

$112 p 40$
b-actin

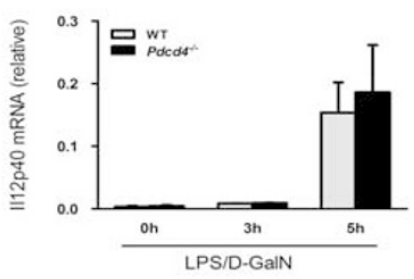

g

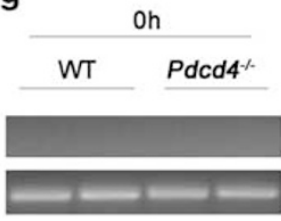

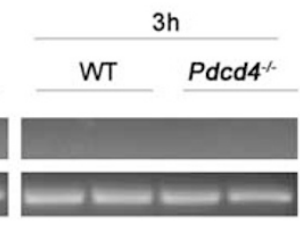

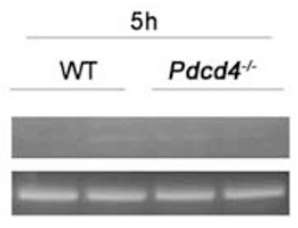

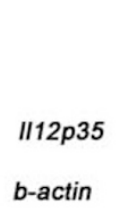

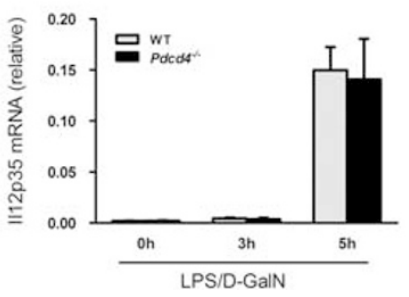

Figure 4 PDCD4 deficiency altered hepatic cytokine levels in LPS/D-GalN-induced acute liver injury. The histogram represented semiquantitative results (mean \pm s.d.) of RT-PCR analysis. ( $n=8$ /group/time point) (a-e) Obviously increased expression of Tnfa, II1b, II6 and Mcp1 and II10 mRNA was observed in $P d c d 4^{-1-}$ mice at $3 \mathrm{~h}$ after LPS/D-GalN administration $\left({ }^{*} P<0.05,{ }^{*} P<0.01\right.$ compared with WT mice). (f, $\left.\mathbf{g}\right)$ There were no significant differences in the expression of $1112 p 40$ and $/ 112 p 35$ mRNA at the same time point between $P d c d 4^{-/-}$mice and WT mice $(P>0.05)$. 
a Oh

$3 \mathrm{~h}$

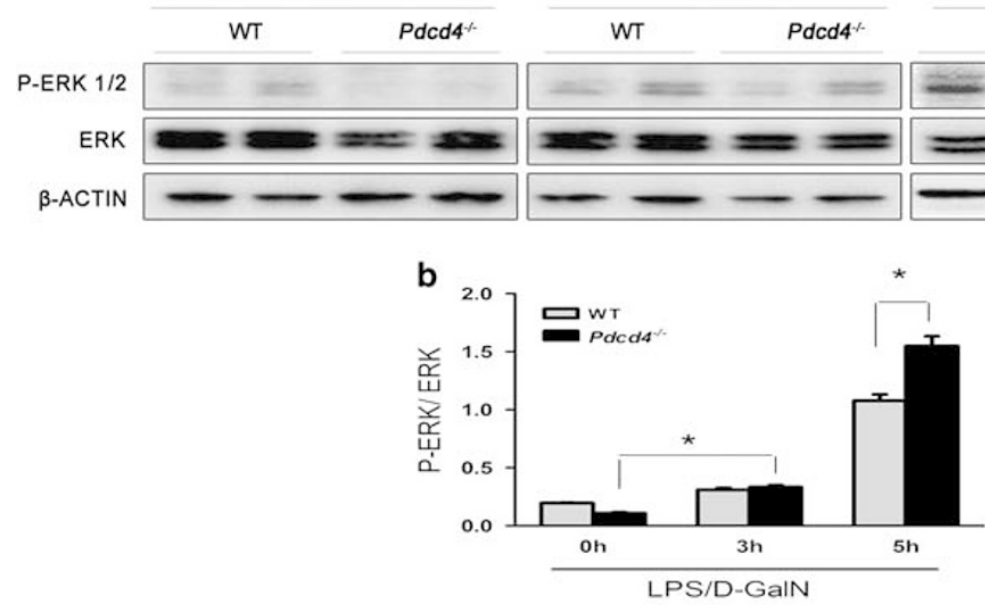

c
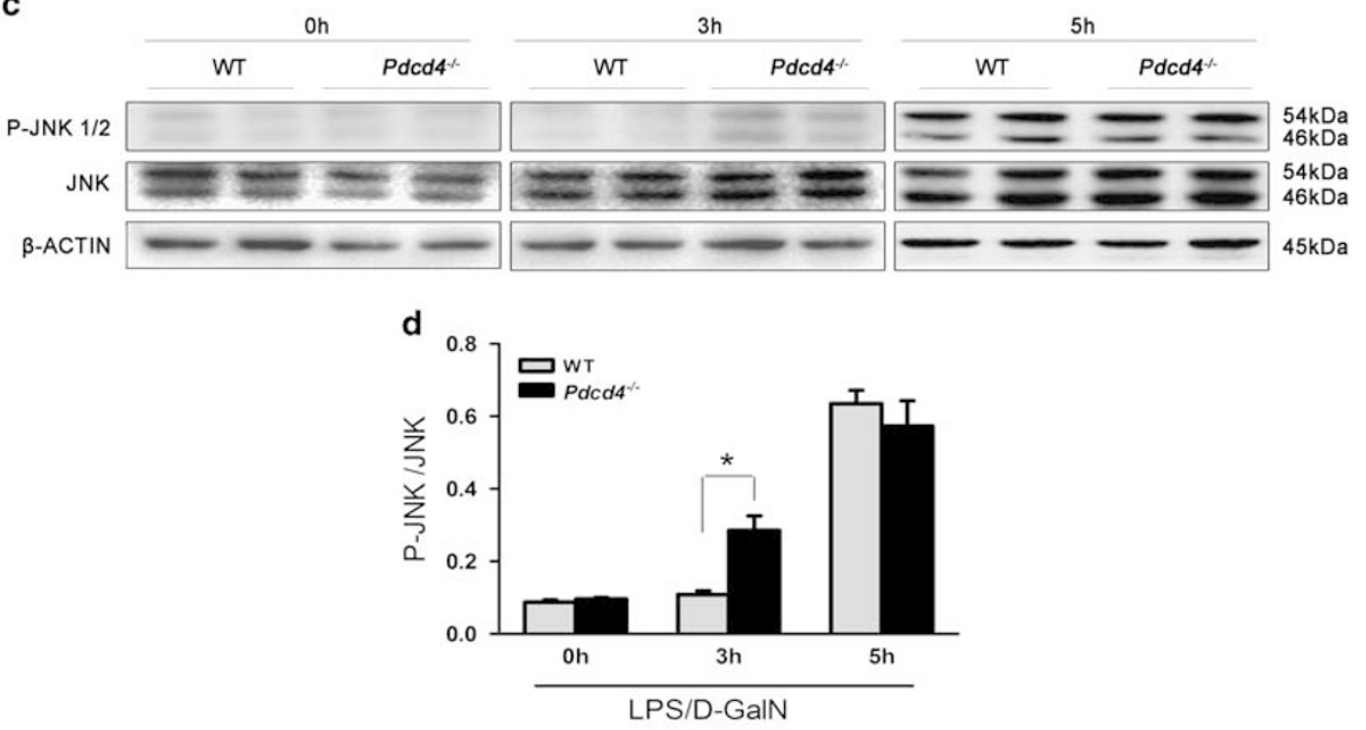

e
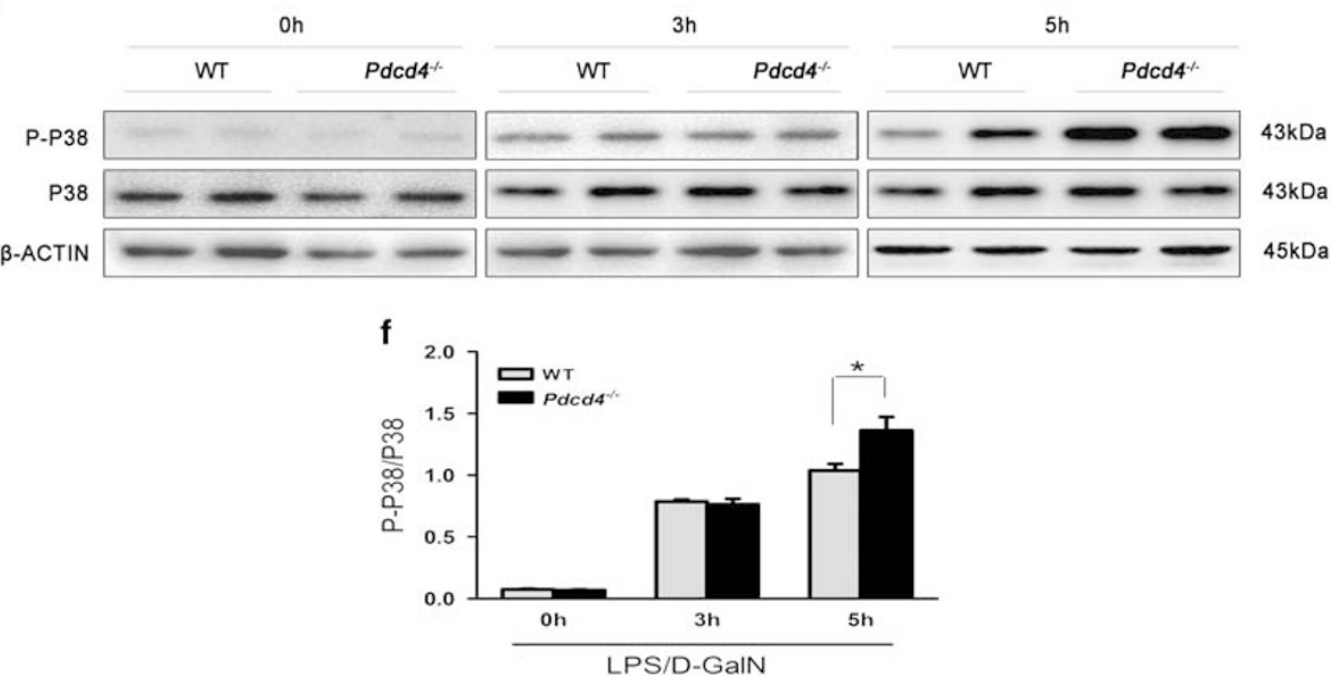

Figure 5 PDCD4 deficiency promotes the LPS-induced activation of MAPK in the liver. The histogram represented semiquantitative results (mean \pm s.d.) of western blot analysis. ( $n=8 /$ group/time point) $(\mathbf{a}, \mathbf{b})$ The level of p-ERK1/2 was significantly higher in Pdcd4 ${ }^{-1-}$ mice than WT mice at $5 \mathrm{~h}$ after LPS/ D-GalN injection $\left({ }^{*} P<0.05\right)$. (c, d) The level of $\mathrm{p}-\mathrm{SAPK} / \mathrm{JNK}$ was significantly higher in $P d c d 4^{-1-}$ mice than WT mice at $3 \mathrm{~h}$ after LPS/D-GalN injection $\left({ }^{*} P<0.05\right)$. (e, f) The level of p-p38 was significantly increased in $P d c d 4^{-1-}$ mice than WT mice at $5 \mathrm{~h}$ after LPS/D-GalN administration $\left({ }^{*} P<0.05\right)$. 
(Figures $5 \mathrm{a}$ and $\mathrm{b}) \cdot \mathrm{p}$-SAPK/JNK levels were also significantly higher in PDCD4-deficient mice than WT mice at $3 \mathrm{~h}$ after LPS/D-GalN injection, and p-SAPK/JNK levels were much higher in both groups at $5 \mathrm{~h}$ after injection, but there was no significant difference between PDCD4-deficient mice and WT mice (Figures $5 c$ and d). In addition, p-p38 levels were significantly increased in PDCD4-deficient mice than WT mice at $5 \mathrm{~h}$ after LPS/D-GalN administration (Figures $5 \mathrm{e}$ and $\mathrm{f}$ ). Thus, early activation of $\mathrm{p}-\mathrm{SAPK} / \mathrm{JNK}$ at $3 \mathrm{~h}$ and late activation of p-ERK1/2, p-P38 at $5 \mathrm{~h}$ were associated with aggravated LPS/D-GalN-induced liver injury in PDCD4deficient mice.

\section{PDCD4 Deficiency Promotes LPS-induced Activation of $\mathrm{NF}-\boldsymbol{\kappa} \mathrm{B}$ in the Liver}

The NF- $\kappa$ B pathway is another important signaling pathway related to LPS-induced production and release of inflammatory cytokines. ${ }^{13,20}$ In order to explore whether the activation of NF- $\kappa \mathrm{B}$ can be involved in LPS/D-GalN-induced liver injury in PDCD4-deficient mice, we detected expression of p-p65 by western blot and immunohistochemical analysis. The results of the western blot showed that there was no significant difference in expression of p-p65 between PDCD4-deficient mice and WT mice at $0 \mathrm{~h}$ after LPS/DGalN injection (Figures $6 \mathrm{a}$ and $\mathrm{b}$ ). However, the level of

a
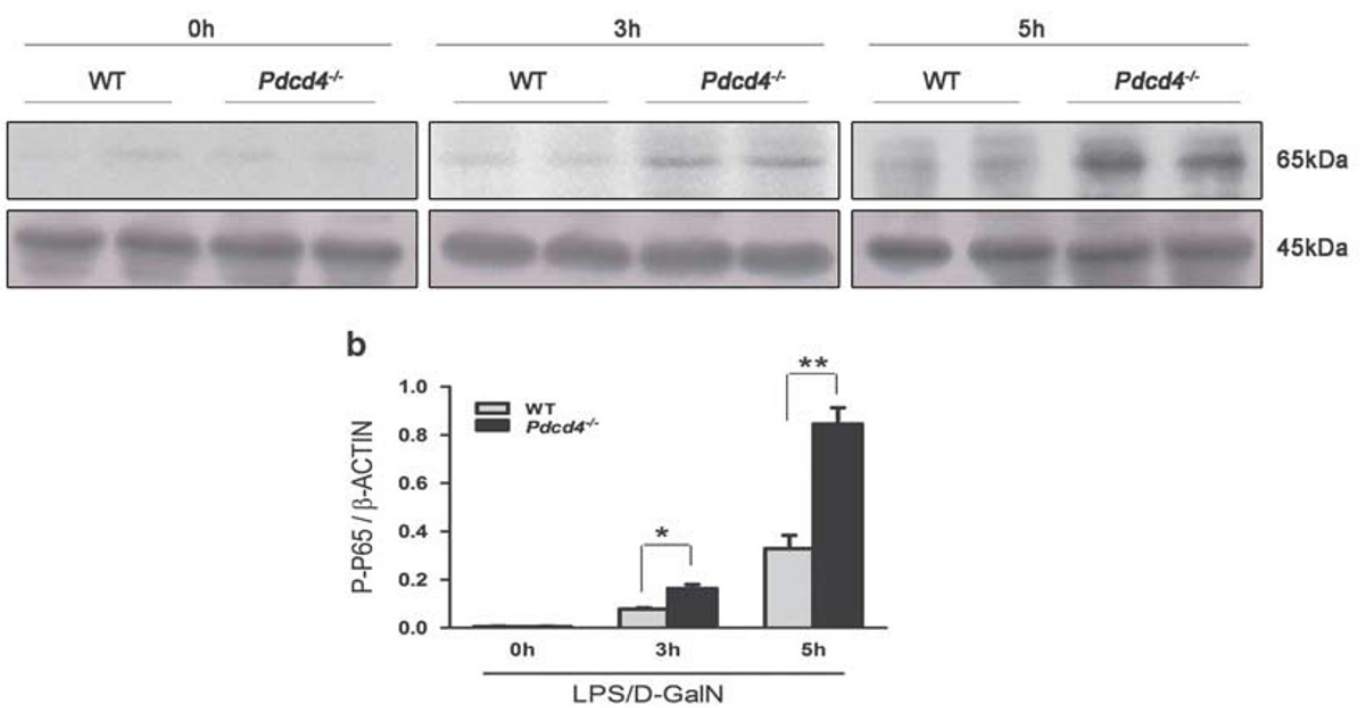

C
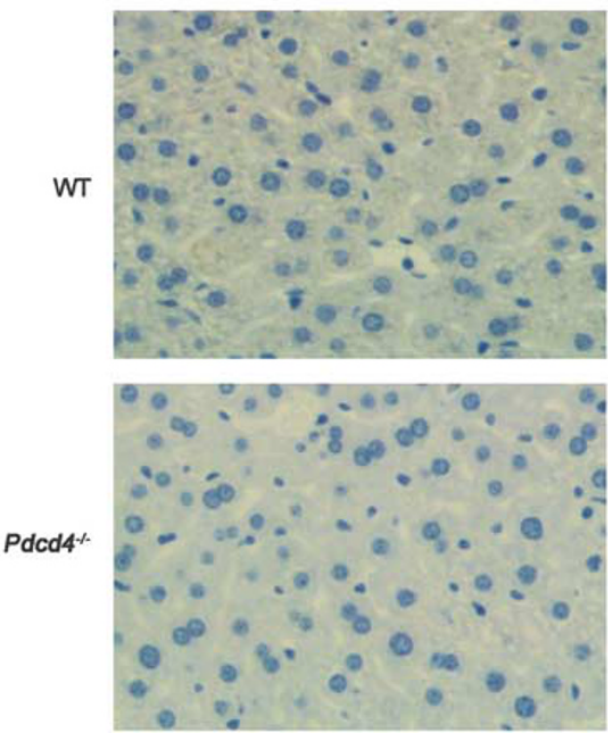

3h
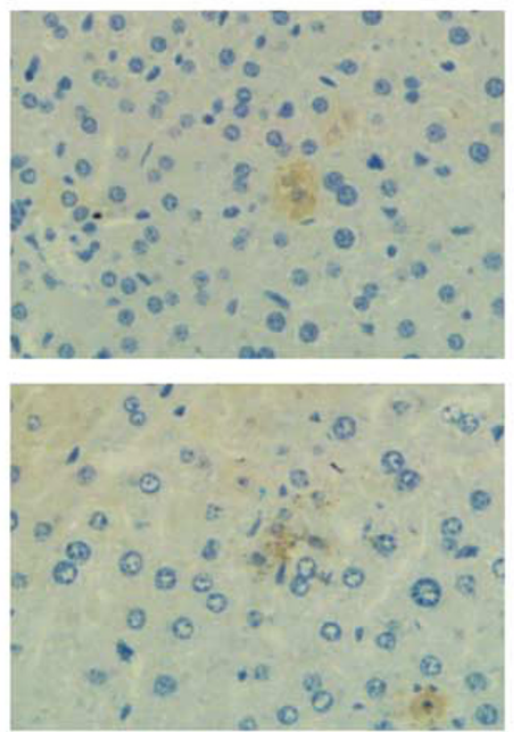

$5 \mathrm{~h}$
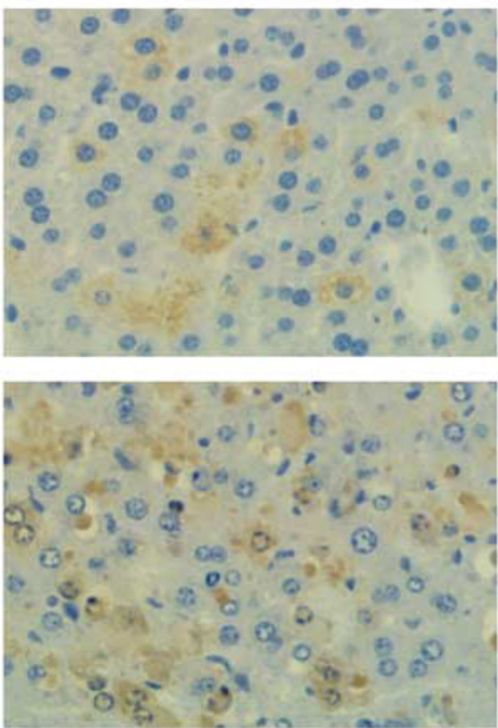

Figure 6 PDCD4 deficiency promotes the LPS-induced activation of NF- $\kappa$ B in the liver. The histogram represented semiquantitative results (mean $\pm \mathrm{s} . \mathrm{d}$.) of western blot analysis. ( $n=8 /$ group/time point) $(\mathbf{a}, \mathbf{b})$ western blot analysis showed the level of p-p65 was significantly higher in Pdcd4 ${ }^{-/-}$mice than WT mice at $3 \mathrm{~h}$ and $5 \mathrm{~h}$ after LPS/D-GalN injection $\left({ }^{*} P<0.05,{ }^{*} P<0.01\right)$. (c) Immunohistochemical analysis also showed stronger expression of p-P65 in liver tissues of $P d c d 4^{-/-}$mice than WT mice at $3 \mathrm{~h}$ and $5 \mathrm{~h}$ after injection. Original magnification: $\times 200$. 
p-p65 expression was significantly higher in PDCD4-deficient mice than WT mice at $3 \mathrm{~h}$ and $5 \mathrm{~h}$ after injection. The results from IHC showed a similar phenomenon (Figure 6c). Thus, these data indicate that PDCD4 deficiency can promote the LPS-induced activation of NF- $\kappa$ B pathway.

\section{DISCUSSION}

Previous studies have shown that PDCD4 is not only a tumor suppressor, ${ }^{21-24}$ but also a regulator in inflammatory processes. ${ }^{25}$ It has been reported that the loss of PDCD4 in macrophages attenuates NF- $\kappa \mathrm{B}$ activation and promotes IL10 production in response to LPS, thereby limiting excessive inflammation. ${ }^{9}$ On the contrary, some other studies suggest that PDCD4 downregulation increases LPS-induced expression of proinflammatory mediators, such as TNF- $\alpha$ in RAW264.7 cells. ${ }^{10}$ Therefore, the exact role of PDCD4 in inflammation remains to be elucidated. The present in vivo study first indicates that compared with WT mice, PDCD4deficient mice secrete more inflammatory cytokines and have more obvious hepatocyte apoptosis and necrosis in response to LPS/D-GalN, which suggests an inhibitory function of PDCD4 in LPS/D-GalN-induced acute liver injury.

After LPS/D-GalN treatment, kupffer cells can secrete various proinflammatory cytokines including TNF- $\alpha$, IL- $1 \beta$, IL-6, as well as anti-inflammatory cytokine IL-10. TNF- $\alpha-$ induced hepatocyte apoptosis and necrosis have been identified as the most important mechanism in LPS/D-GalNinduced liver injury. ${ }^{26}$ In our current study, an overproduction of proinflammatory cytokines was observed at $3 \mathrm{~h}$ after LPS/D-GalN injection. Our results showed that PDCD4-deficient mice had significantly higher hepatic Tnfa, Il6, Mcp1 and Illb mRNA expression as well as serum TNF- $\alpha$, IL-6 and MCP-1 levels at $3 \mathrm{~h}$ after LPS/D-GalN injection compared with WT mice. However, there was no obvious liver injury at $3 \mathrm{~h}$ after injection. At this time point, PDCD4deficient mice showed slightly lower serum ALT and AST levels and a little higher liver-to-body weight ratios, TUNELpositive cells and caspase- 3 activity than WT mice, but they did not achieve statistical significance and there were also no obvious pathological changes in the two groups. Five hours later, the expression of proinflammatory cytokines was not significantly different between PDCD4-deficient mice and WT mice. However, LPS/GalN-induced liver injury was potentiated in PDCD4-deficient mice. Compared with WT mice, PDCD4-deficient mice showed more obvious indicators of acute liver injury, such as increased liver-tobody weight ratios, serum ALT and AST levels, hepatocyte apoptosis or necrosis. The direct effect of apoptosis-related gene PDCD4 on apoptosis has been studied. Most reports showed that PDCD4 was a pro-apoptosis gene. ${ }^{27-30}$ However, recently a study showed that PDCD4 was an antiapoptotic regulator that inhibited the translation of procaspase-3 mRNA in cells. ${ }^{31}$ In our study, there was no significant difference in hepatocyte apoptosis between PDCD4-deficient mice and WT mice at $0 \mathrm{~h}$ after LPS/D-GalN injection.
Therefore, our results indicate PDCD4 deficiency increases the production of proinflammatory cytokines, these cytokines in turn promote hepatocyte apoptosis. In addition, we found increased IL-10 expression in PDCD4deficient mice at $3 \mathrm{~h}$ after LPS/D-GalN injection. This may be the reason that there was no significant difference in the expression of proinflammatory cytokines between PDCD4deficient mice and WT mice at $5 \mathrm{~h}$ after LPS/D-GalN injection. Taken together, our results indicate that the lack of PDCD4 induces aggravation of liver injury, which may be mediated by the mechanism depending on early proinflammatory cytokine production in response to LPS.

In LPS/D-GalN-induced acute liver injury, production of TNF- $\alpha$, IL- 6 and IL- $1 \beta$ mainly depends on the activation of two distinct signaling pathways, including MAPK and NF- $\kappa \mathrm{B}$ pathways. LPS activates kupffer cells by initiating the TLR4 signaling cascade, ${ }^{32,33}$ induces the production of inflammatory cytokines via MyD88-dependent activation of MAPK (ERK1/2, JNK1/2 and p38) and NF- $\kappa$ B pathways. ${ }^{34}$ PDCD4, which acts as a translation inhibitor, ${ }^{35,36}$ has been reported to inhibit c-Jun activation and AP-1-dependent transcription by downregulating the expression of MAPK kinase kinase kinase $1 /$ hematopoietic progenitor kinase 1 , a kinase upstream of $\mathrm{JNK}^{37}$ This result indicates PDCD4 participates in the regulation of the MAPK pathway in tumors. ${ }^{38,39}$ In our present study, we first demonstrate that PDCD4 deficiency promotes activation of the LPS-mediated MAPK pathway. Our results showed that the level of hepatic p-JNK1/2 was significantly higher in PDCD4-deficient mice, and the levels of inflammatory cytokines were also obviously increased in PDCD4-deficient mice at $3 \mathrm{~h}$ after LPS/D-GalN injection. Thus, the early activation of JNK1/2 may promote the release of inflammatory factors in PDCD4-deficient mice. It has been reported that SP600125, an inhibitor of JNK, attenuated LPS-induced liver injury, ${ }^{15,40}$ and JNK knockout mice resisted TNF- $\alpha$-induced liver injury. ${ }^{15,41,42}$ This data indicate the activation of JNK also promotes hepatocyte apoptosis and liver injury. At $5 \mathrm{~h}$ after LPS/D-GalN injection, the levels of p-ERK1/2 and p-p38 were much higher in PDCD4-deficient mice than WT mice, which may be because increased inflammatory factors such as TNF- $\alpha$ further accelerate the activation of ERK1/2 and p38. Previous studies showed that TNF- $\alpha$ induced the activation of ERK1/2 and p38 and regulated cell proliferation, differentiation and apoptosis. ${ }^{43}$ The activation of ERK and P38 has both proapoptotic and antiapoptotic functions in TNF- $\alpha$-mediated apoptosis depending on cell type or model of injury. An increasing number of studies have demonstrated that activation of ERK1/2 is associated with tissue injury including liver etc, ${ }^{44,45}$ but it is also reported that ERK1/2 promotes cell survival. ${ }^{15}$ Our results showed that the level of $\mathrm{p}$-ERK1/2 was significantly higher in PDCD4-deficient mice and obvious hepatocyte apoptosis occurred at $5 \mathrm{~h}$ post LPS/D-GalN treatment. Therefore, ERK may have a proapoptosis and pro-death role at a later time 
point in LPS/D-GalN-induced liver injury, and the higher levels of p-ERK1/2 in PDCD4-deficient mice aggravate LPS/ $\mathrm{D}$-GalN-induced hepatocyte apoptosis and liver injury. In addition, it has been reported that hepatocyte p38 $\alpha$ deficiency promoted LPS-induced apoptosis of hepatic cells ${ }^{46}$ whereas p38 inhibitor SB203580 protected mice from LPS-induced liver injury through antioxidative stress mechanisms. ${ }^{40}$ Our results showed that level of p-p38 was higher in PDCD4-deficient mice than WT mice at $5 \mathrm{~h}$ after injection, which is associated with aggravated LPS/D-GalN-induced hepatocytes apoptosis and liver injury. Taken together, our results indicate that the loss of PDCD4 facilitates LPS/D-GalN-induced activation of JNK, increases the production and release of inflammatory cytokines such as TNF- $\alpha$, which further promotes the activation of ERK and p-38 and leads to the aggravation of hepatocyte apoptosis and necrosis.

The NF- $\kappa$ B pathway is another important signaling pathway participating in LPS-induced inflammatory cytokines release. ${ }^{13,20}$ PDCD4 not only controls gene transcription by regulating $\mathrm{AP}-1,{ }^{47,48}$ but also affects the expression of cytokines by regulating the NF- $\kappa \mathrm{B}$ pathway. ${ }^{9}$ It has been reported that the loss of PDCD4 inhibits the activation of $\mathrm{NF}-\kappa \mathrm{B}$ and promotes the production of IL-10 in macrophages after LPS treatment. ${ }^{9}$ The effect of PDCD4 on $\mathrm{NF}-\kappa \mathrm{B}$ activation is not due to modulation of the IKK complex and is probably JNK activation to be impaired in response to LPS. ${ }^{9}$ However, our present study showed that the levels of p-p65 and p-JNK were significantly higher in PDCD4-deficient mice, and the levels of inflammatory cytokines were also obviously increased in PDCD4-deficient mice at $3 \mathrm{~h}$ after LPS/D-GalN injection. Therefore, PDCD4 deficiency may promote LPS-induced activation of JNK, $\mathrm{NF}-\kappa \mathrm{B}$ and release of inflammatory cytokines, and PDCD4 may have an inhibitory effect on the activation of NF- $\kappa \mathrm{B}$ in our model. In addition, at $5 \mathrm{~h}$ after LPS/D-GalN injection, the level of p-p65 was still significantly higher in PDCD4deficient mice than WT mice. The further activation of p65 may be due to the increased release of inflammatory cytokines. In particular, TNF- $\alpha$ can initiate a downstream death-receptor pathway and NF- $\kappa \mathrm{B}$ pathway. The activation of NF- $\kappa$ B pathway also regulates antiapoptotic proteins and protects cells from TNF- $\alpha$-induced apoptosis. ${ }^{41,49}$ Defective NF- $\kappa$ B signaling causes severe hepatocyte apoptosis and uncontrolled TNF- $\alpha$ toxicity. ${ }^{50}$ Therefore, our results indicate that the loss of PDCD4 enhances the activation of p65, which may promote the release of inflammatory cytokines. The increased levels of cytokines further promote the activation of NK- $\kappa \mathrm{B}$ and have a negative-feedback role in TNF- $\alpha-$ induced apoptosis.

In conclusion, the current study shows an inhibitory action of PDCD4 in LPS/D-GalN-induced acute liver injury and some molecular mechanisms have been found: the loss of PDCD4 increases the sensitivity of liver injury and hepatocytes apoptosis by promoting the production and release of inflammatory cytokines, and this action is mediated by the excessive activation of the MAPK and NF- $\kappa$ B pathways. Thus, PDCD4 appears to have a protective role in LPS/D-GalNinduced acute liver injury. This finding might present new opportunities for PDCD4 to be explored as a therapeutic target in acute liver injury.

Supplementary Information accompanies the paper on the Laboratory Investigation website (http://www.laboratoryinvestigation.org)

\section{ACKNOWLEDGEMENTS}

We thank Dr Youhai Chen (Department of Pathology and Laboratory Medicine, School of Medicine, University of Pennsylvania, Philadelphia, USA) for the PDCD4-deficient mice and WT C57BL/6 mice. We also thank Dr Xiao Wang (Department of Pathology and Pathophysiology, Shandong University School of Medicine, Jinan, China) for pathological observation. This work was supported by the National Natural Science Foundation of China (81172863), Natural Science Foundation of Shandong (ZR2009CM013, ZR2012HM091), Independent Innovation Foundation of Shandong University (2012ZD045), Postdoctoral Innovation Program of Shandong Province (201102015), China Postdoctoral Science Foundation funded project (2012M511034).

\section{DISCLOSURE/CONFLICT OF INTEREST}

The authors declare no conflict of interest.

1. Lankat-Buttgereit B, Göke R. Programmed cell death protein 4 (pdcd4):A novel target for antineoplastic therapy. Biol cell 2003;95:515-519.

2. Lankat-Buttgereit B, Göke. R. The tumour suppressor Pdcd4: recent advances in the elucidation of function and regulation. Biol Cell 2009;101:309-317.

3. Wang X, Wei Z, Gao F, et al. Expression and prognostic significance of PDCD4 in human epithelial ovarian carcinoma. Anticancer Res 2008;28:2991-2996.

4. Wei ZT, Zhang $X$, Wang XY, et al. PDCD4 inhibits the malignant phenotype of ovarian cancer cells. Cancer Sci 2009;100:1408-1413.

5. Zhang X, Wang X, Song X, et al. Programmed cell death 4 enhances chemosensitivity of ovarian cancer cells by activating death receptor pathway in vitro and in vivo. Cancer Sci 2010;101:2163-2170.

6. Gao F, Wang X, Zhu F, et al. PDCD4 gene silencing in gliomas is associated with $5^{\prime} \mathrm{CpG}$ island methylation and unfavourable prognosis. J Cell Mol Med 2009;13:4257-4267.

7. Gao F, Zhang P, Zhou C, et al. Frequent loss of PDCD4 expression in human glioma: possible role in the tumorigenesis of glioma. Oncol Rep 2007;17:123-128.

8. Hilliard A, Hilliard B, Zheng SJ, et al. Translational regulation of autoimmune inflammation and lymphoma genesis by programmed cell death 4. J Immunol 2006;177:8095-8102.

9. Sheedy FJ, Palsson-McDermott E, Hennessy EJ, et al. Negative regulation of TLR4 via targeting of the proinflammatory tumor suppressor PDCD4 by the microRNA miR-21. Nat Immunol 2010;11:141-147.

10. Yasuda M, Schmid T, Rübsamen D, et al. Downregulation of programmed cell death 4 by inflammatory conditions contributes to the generation of the tumor promoting microenvironment. Mol Carcinog 2010;49:837-848.

11. Nolan JP. The role of intestinal endotoxin in liver injury: a long and evolving history. Hepatology 2010;52:1829-1835.

12. Han DW. Intestinal endotoxemia as a pathogenetic mechanism in liver failure. World J Gastroenterol 2002;8:961-965.

13. Nowak M, Gaines GC, Rosenberg J, et al. LPS-induced liver injury in D-galactosamine-sensitized mice requires secreted TNF-alpha and the TNF-p55 receptor. Am J Physiol Regul Integr Comp Physiol 2000;278:R1202-R1209.

14. Guha M, Mackman N. LPS induction of gene expression in human monocytes. Cell Signal 2001;13:85-94. 
15. Galanos C, Freudenberg MA, Reutter W. Galactosamine-induced sensitization to the lethal effects of endotoxin. Proc Natl Acad Sci USA 1979;76:5939-5943.

16. Mignon A, Rouquet N, Fabre $M$, et al. LPS challenge in D-galactosamine -sensitized mice accounts for caspase-dependent fulminant hepatitis, not for septic shock. Am J Respir Crit Care Med 1999;159(4 Pt 1):1308-1315.

17. Wang K, Damjanov I, Wan YJ. The protective role of pregnane $X$ receptor in lipopolysaccharide/D-galactosamine-induced acute liver injury. Lab Invest 2010;90:257-265.

18. Kuhla A, Eipel C, Abshagen K, et al. Role of the perforin/granzyme cell death pathway in D-Gal/LPS-induced inflammatory liver injury. Am J Physiol Gastrointest Liver Physiol 2009;296:G1069-G1076.

19. Shang $Y$, Liu Y, Du L, et al. Targeted expression of uncoupling protein 2 to mouse liver increases the susceptibility to lipopolysaccharide/ galactosamine -induced acute liver injury. Hepatology 2009;50: 1204-1216.

20. Li G, Qi XP, Wu XY, et al. Verapamil modulates LPS-induced cytokine production via inhibition of NF-kappa B activation in the liver. Inflamm Res 2006;55:108-113.

21. Cmarik JL, Min H, Hegamyer G, et al. Differentially expressed protein Pdcd4 inhibits tumor promoter-induced neoplastic transformation. Pro Nati Acad Sci USA 1999;96:14037-14042.

22. Lankat-Buttgereit B, Gregel C, Knolle A, et al. Pdcd4 inhibits growth of tumor cells by suppression of carbonic anhydrase type II. Mol Cell Endocrinol 2004;214:149-153.

23. Jansen AP, Camalier CE, Colbum NH. Epidermal expression of the translation inhibitor programmed cell death 4 suppresses tumorigenesis. Cancer Res 2005;65:6034-6041.

24. Leupold JH, Yang HS, Colburn NH. Tumor suppressor Pdcd4 inhibits invasion/intravasation and regulates urokinase receptor (u-PAR) gene expression via Sp-transcription factors. Oncogene 2007;26:4550-4562.

25. Ruan Q, Wang T, Kameswaran V, et al. The microRNA-21-PDCD4 axis prevents type 1 diabetes by blocking pancreatic beta cell death. Proc Natl Acad Sci USA 2011;108:12030-12035.

26. Liu LM, Zhang JX, Luo J, et al. A role of cell apoptosis in Lipopolysaccharide (LPS)-induced nonlethal liver injury in D-galactosamine (D-GalN)-sensitized rats. Dig Dis Sci 2008;53:1316-1324.

27. Afonja O, Juste D, Das S, et al. Induction of PDCD4 tumor suppressor gene expression by RAR agonists, antiestrogen and HER-2/neu antagonist in breast cancer cells. Evidence for a role in apoptosis. Oncogene 2004;23:8135-8145.

28. Zhang H, Ozaki I, Mizuta T, et al. Involvement of programmed cell death 4 in transforming growth factor-b1-induced apoptosis in human hepatocellular carcinoma. Oncogene 2006;25:6101-6112.

29. Jin $\mathrm{H}$, Kim TH, Hwang SK, et al. Aerosol delivery of urocanic acidmodified chitosan/programmed cell death 4 complex regulated apoptosis, cell cycle, and angiogenesis in lungs of K-ras null mice. Mol Cancer Ther 2006;5:1041-1049.

30. Bhatti I, Lee $A$, James $V$, et al. Knockdown of microRNA-21 inhibits proliferation and increases cell death by targeting programmed cell death 4 (PDCD4) in pancreatic ductal adenocarcinoma. J Gastrointest Surg 2011;15:199-208.

31. Eto K, Goto S, Nakashima W, et al. Loss of programmed cell death 4 induces apoptosis by promoting the translation of procaspase-3 mRNA. Cell Death Differ 2012;19:573-581.
32. Akira S. Toll-like receptor signaling. J Biol Chem 2003;278: 38105-38108.

33. Akira $\mathrm{S}$, Sato $\mathrm{S}$. Toll-like receptors and their signaling mechanisms Scand J Infect Dis 2003;35:555-562.

34. Hanada T, Yoshimura A. Regulation of cytokine signaling and inflammation. Cytokine Growth Factor Rev 2002;13:413-421.

35. Yang HS, Jansen AP, Komar AA, et al. The transformation suppressor Pdcd4 is a novel eukaryotic translation initiation factor 4A binding protein that inhibits translation. Mol Cell Biol 2003;23:26-37.

36. Loh PG, Yang HS, Walsh MA, et al. Structural basis for translational inhibition by the tumour suppressor Pdcd4. EMBO J 2009;28:274-285.

37. Yang HS, Matthews CP, Clair T, et al. Tumorigenesis suppressor Pdcd4 down-regulates mitogen-activated protein kinase kinase kinase kinase 1 expression to suppress colon carcinoma cell invasion. Mol Cell Biol 2006;26:1297-1306.

38. Yang HS, Knies JL, Stark C, et al. Pdcd4 suppresses tumor phenotype in JB6 cells by inhibiting AP-1 transactivation. Oncogene 2003;22: 3712-3720.

39. Bitomsky N, Böhm M, Klempnauer KH. Transformation suppressor protein Pdcd4 interferes with JNK-mediated phosphorylation of c-Jun and recruitment of the coactivator p300 by c-Jun. Oncogene 2004;23:7484-7493.

40. Wu D, Cederbaum A. Cytochrome P4502E1 sensitizes to tumor necrosis factor alpha-induced liver injury through activation of mitogen-activated protein kinases in mice. Hepatology 2008;47:1005-1017.

41. Chang L, Kamata H, Solinas G, et al. The E3 ubiquitin ligase itch couples JNK activation to TNF alpha-induced cell death by inducing c-FLIP(L) turnover. Cell 2006;124:601-613.

42. Wang $\mathrm{Y}$, Singh $\mathrm{R}$, Lefkowitch $\mathrm{JH}$, et al. Tumor necrosis factor-induced toxic liver injury results from JNK2-dependent activation of caspase-8 and the mitochondrial death pathway. J Biol Chem 2006;281: $15258-15267$.

43. Wajant $\mathrm{H}$, Pfizenmaier $\mathrm{K}$, Scheurich $\mathrm{P}$. Tumor necrosis factor signaling. Cell Death Differ 2003;10:45-65.

44. Haimerl F, Erhardt A, Sass G, et al. Down-regulation of the deubiquitinating enzyme ubiquitin-specific protease 2 contributes to tumor necrosis factor-alpha-induced hepatocyte survival. J Biol Chem 2009;284:495-504.

45. Zhai $Y$, Shen XD, Gao F, et al. CXCL10 regulates liver innate immune response against ischemia and reperfusion injury. Hepatology 2008;47:207-214.

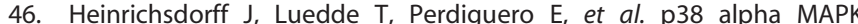
inhibits JNK activation and collaborates with IkappaB kinase 2 to prevent endotoxin-induced liver failure. EMBO Rep 2008;9:1048-1054.

47. Wang Q, Sun Z, Yang HS. Downregulation of tumor suppressor Pdcd4 promotes invasion and activates both beta-catenin/Tcf and AP-1dependent transcription in colon carcinoma cells. Oncogene 2008:27:1527-1535

48. Wang Q, Zhang Y, Yang HS. Pdcd4 knockdown up-regulates MAP4K1 expression and activation of AP-1 dependent transcription through c-Myc. Biochim Biophys Acta 2012;1823:1807-1814.

49. Karin M, Lin A. NF-kappaB at the crossroads of life and death. Nat Immunol 2002:3:221-227.

50. Beg AA, Sha WC, Bronson RT, et al. Embryonic lethality and liver degeneration in mice lacking the RelA component of NF-kappa B. Nature 1995;376:167-170 